\title{
Mineral composition of bambaranut - tigernut - coconut mil beverage blends
}

\author{
Okorie Stanislaus Udeze ${ }^{1}$, Adedokun Isiaka Ishola ${ }^{2}$, Nwachukwu Chijioke Nnaemeka ${ }^{1}$, \\ Ihemeje Austine ${ }^{1}$ \\ ${ }^{1}$ Departmentof Food Science and Technology, Faculty of Engineering Imo State University, Owerri, Imo State, Nigeria \\ ${ }^{2}$ Departmentof Food Science and Technology, Imo State Polytechnics Umuagwo, Imo State, Nigeria
}

Email address:

stanudeokorie@gmail.com (Okorie S. U.)

To cite this article:

Okorie Stanislaus Udeze, Adedokun Isiaka Ishola, Nwachukwu Chijioke Nnaemeka, Ihemeje Austine. Mineral Composition of Bambaranut - Tigernut - Coconut Mil Beverage Blends. Journal of Food and Nutrition Sciences. Vol. 2, No. 5, 2014, pp. $231-235$. doi: $10.11648 /$ j.jfns.20140205.15

\begin{abstract}
Mineral composition of bambaranut-tigernut-coconut milk beverage blends was conducted. This aimed to assess the amount of calcium, potassium, iron, zinc, phosphorus and magnesium in the blends and compare with standards. Four blends of milk beverage were formulated using different ratios of 1:1:1, 3:2:1, 2:3:1 and 1:3:2 from single milk extraction from babaranut, tigernut and coconut respectively. Two control samples were made from 100\% bambaranut and tigernut milk respectively. The samples were subjected to mineral (calcium, potassium, iron, zinc, phosphorus and magnesium) analysis using standard assay method. The result showed that the values of mineral element per $100 \mathrm{~g}$ ranged from $8.34-18.20 \mathrm{mg}$ calcium, $1.82-4.24 \mathrm{mg}$ potassium, $0.86-2.25 \mathrm{mg}$ iron, $1.02-3.38 \mathrm{mg} \mathrm{zinc,} 1.15-2.97 \mathrm{mg}$ phosphorous and $0.87-1.24 \mathrm{mg}$ magnesium. This study has revealed that the blends are good source of minerals however, it was below the quantity contained in milk. This work can be improved on by as well as subjecting the blends to further research to check the level of antinutrients and to know the bioavailability of the minerals. It is therefore recommended that this study be replicated in different parts of the world. Industries are encouraged to adopt the methodology to produce it in larger quantities for commercialization to help fight hidden hunger that is ravaging the world today.
\end{abstract}

Keywords: Mineral, Bambaranut- Tigernut - Coconut, Milk Beverage Blends

\section{Introduction}

Any liquid that replaces milk in the diet is called milk substitute. The general term for any milk-like product that is derived from a plant source is called Plant milk. Plant milks have been a century aged drinks both as regular drinks (such as the Spanish horchata) and as a substitute for milk, such as by some Christian denominations during Lent. The most popular varieties internationally are soy milk, almond milk, rice milk and coconut milk ${ }^{(1-2)}$. Because of the cost of dairy milk in developing countries, there is a big shift towards the consumption of plant milk (milk substitute $)^{(3)}$. Though undervalued in the past, milk from plant sources are key ingredients in the diet of African countries. Researchers have recently shown strong interest in these milk sources due to their nutrient composition and economic potentials ${ }^{(3)}$.

"Minerals and trace elements are essential to the good functioning of the body and they have to be supplied by the food. The major nutritional interest in milk and milk products may lie in their natural richness in calcium but they are also among the main suppliers of phosphorus, iodine, magnesium, zinc and selenium" (4).

Legume crops are known to be rich in plant protein and minerals as well as dietary fibre especially soybeans among others recently have received very high research attention and more research is still being developed to improve the quality of soy milk ${ }^{(5)}$, yet, supply and demand has not been met due to the increase in world population apart from its high cost like cow milk. It is important to note however, that little research attention has been given to other legumes like bambaranut, baobab, peanut melon seed, and tigernut milk ${ }^{(6-10)}$ as sources of single or blended ready-toserve bottled beverage, like "Horchata de chufas" as done 
in South Europe, especially Spain.

Tiger-nut (Cyperusesculentus L.) belongs to the Division - Magnoliophyta, Class - Liliopsida, Order - Cyperales and Family - Cyperaceae and was found to be a cosmopolitan, perennial crop of the same genus as the papyrus plant ${ }^{(3)}$. It is abundantly produced in Nigeria especially, in the northern part of Nigeria. Tiger-nut is called by different names and also it has different names in different Nigerian languages, these include: Zulu nut, yellow nut grass, ground almond, chafu, edible rush and rush nut and in Nigeria, it is called "Aya", in Hausa, "imumu" in Yoruba, "aki Hausa" in Igbo, and "ofio" in southern Nigeria (11). Report showed that tiger-nut is an under-utilized crop, but the nut itself has good nutritional potentials, it nutrient composition include: 5.8\% moisture, rich in protein $(7 \%)$, carbohydrate such as reducing sugar $(7.4 \%)$, soluble polysaccharide $(7.4 \%)$ and starch $(86.4 \%)^{(12}$ ${ }^{-13)}$.Ojobe and Tempo $\left({ }^{14)}\right.$ reported that the protein in tiger-nut is of high biological value because of the many essential amino acids present in it. These amino acides are exceeded those proposed in the standard by the FAO/WHO, ${ }^{(15-16)}$ and satisfy amino acid requirement of adults ${ }^{(17)}$. Considering its nutritional potentials, that necessited this research to also check the level of minerals present in this valuable crop when it is processed into milk and beverage blends.

Bambara groundnut (Vigna subterranean (L.)Verdc.)another species of legume originating from African. Report has it that in Nigeria, bambara groundnut is widely produced in Borno, Anambra, Plateau, Taraba, Sokoto, Bauch, Benue, Kano, Yobe, Adamawa and Gombe states. Bambara groundnut as reported contains crude protein $20.60 \%$, it is high in lysine with fair amount of total sulphur amino acids. The seed is deficient in tryptophan, the bulk of the fat is unsaturated (about $59 \%$ ) while $41 \%$ is saturated ${ }^{(18-}$ 20). Despite its economic importance, no noticeable industrial use of the crop has taken place in Nigeria upon its high annual yield ${ }^{(19)}$.

Coconut (Cocusnucifera) is commonly known as the stone of the drupes borne by the coconut palm. It is a monocotyledonous plant in the family Palmae. It is known as the "wonder food" and is regarded as perfect diet because it contains almost all essential nutrients needed by the human body ${ }^{(21)}$.Coconut (Cocusnucifera) milk is popularly known to a good raw material for industries producing confectionaries, bakeries, biscuits and ice cream worldwide to enhance flavor and taste of various products ${ }^{(22)}$. Coconut juice is found to be rich in calcium, protein and fat. It was as well reported that it is high in minerals and vitamin ${ }^{(23)}$.

Therefore, having considered the nutritional potentials of these crops, it is important to produce a beverage blend with their milk that may have a potential to substitute animal sourced milk. The present research was aimed towards evaluation of mineral content of this three "wonderful crops" and to compare with the standards and determine its potential to substitute animal milk.

\section{Materialsand Methods}

\subsection{Material Collection}

Two of the local raw materials (Bambara-nut and Tigernut) were purchased from Ama-Hausa Market, Owerri. Freshly harvested coconut fruits were obtained from a local farm located at Umuagwo in Ohaji-Egbema L.G.A of Imo State. Sucrose (sweetener) and food grade emulsifier was purchased from De-Cross Ltd Lagos. Serile pre-formed plastic bottles were obtained from Tenth April Ltd Mbieri Area Mbaitoli L.G.A for packaging and storage. Processing facilities and equipments were obtained from Department of Food Science and Technology, Imo State University and Imo State Polytechnic, respectively.

\subsection{Preparation of Bambaranut Milk}

The method described by Adedokun, et al, ${ }^{(19)}$ (Figure 1) for the production of milk substitute was used in the extraction of bambara-nut milk. The nuts of babaranut 'Nav Red' variety was manually sorted, cleaned with portable water and soaked in $(4.1 \mathrm{w} / \mathrm{v})$ portable waster for $24 \mathrm{~h}$, while water used in soaking was changed at every $6 \mathrm{~h}$ interval during the soaking duration. The seed coat of the nuts was dehulled after $8 \mathrm{hrs}$ of soaking by rubbing the seeds with the palm and the husks were sieved out of the water and subsequently wet milled using hammer mill. Cheese cloth was used in the extraction of milk from the bambaranut mash by triple filtered by folding the cheese cloth thrice and stored in a sterile white container for further use.

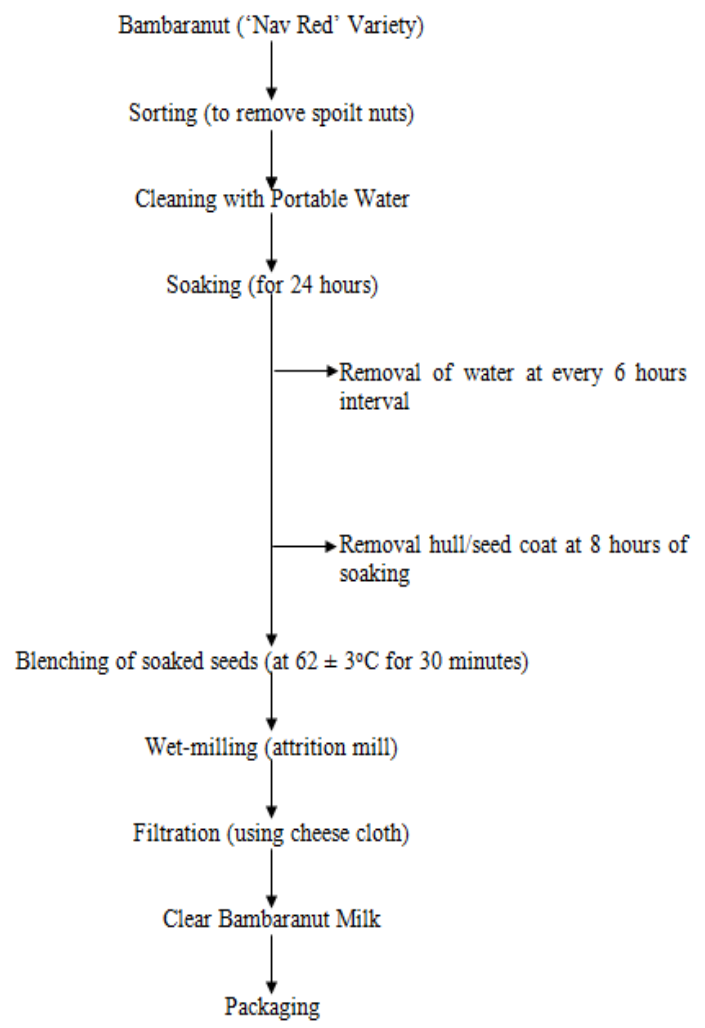

Figure 1. Flow chart for the production of Bambaranut Milk 


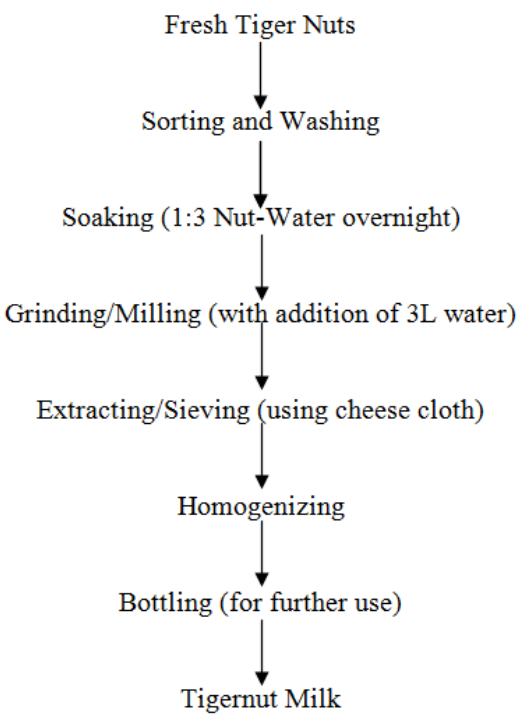

Figure 2. Flow chart for the production of Tigernut Milk

\subsection{Tiger-Nut Milk Preparation}

The method described by Udeozor ${ }^{(24)}$ (Figure 2) was modified for the extraction of tiger-nut milk. One kilogram $(1 \mathrm{~kg})$ of the fresh tiger nuts was manually sorted and cleaned to remove foreign particles and unwanted materials. The nuts were soaked in portable water at ratio nut: water (1:3) overnight. The soaked nut was milled into slurry using fabricated attrition several times with addition of $3 \mathrm{~L}$ of water. The slurry was pressed using muslin cloth to extract the milk. The extracted liquor homogenized using Q-Link Blender (Model 365XG), rapidly cooled and stored in a white sterile 4 litres container.

\subsection{Preparation of Coconut Milk Extract}

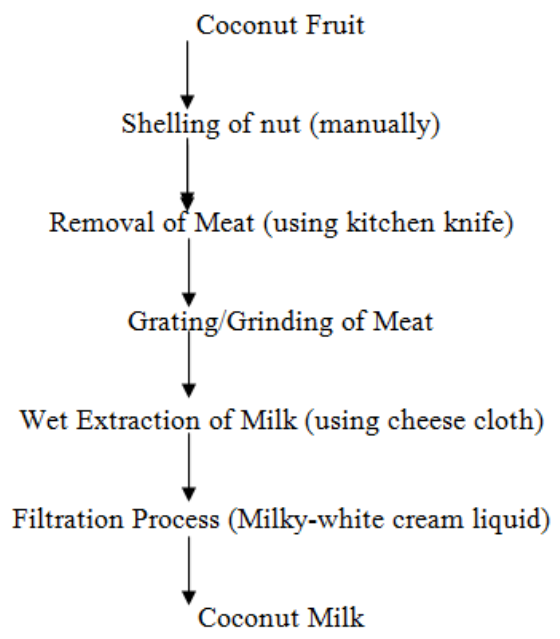

Figure 3. Flow chart for the processing of Coconut Milk

The method (Figure 3) described by Belewu and Belewu $^{(3)}$ was used in the extracting of coconut milk. Coconut milk was prepared by shelling the nut and the meat was separated from the shell using a dull knife. The brown skin was removed from the coconut meat with a razor blade and the meat was thoroughly washed and later grated using attrition mill. The grated meat was put in a bowl and a liter warm water was added and left for a few minutes to extract the oil, milk and the aromatic compounds with cheese cloth. The extract was later filtered with $0.18 \mathrm{~mm}$ sieve and squeezed, so as to obtain a milkywhite opaque emulsion with a sweet coconut flavour while the chaff was discarded.

\subsection{Production of Bambaranut-Tigernut-Coconut Milk Beverage (BTCB)}

Unpasteurized Bambaralnut Milk (BM), Tigernut Milk (TM) and Coconut Milk (CM) was mixed together using varying ratio of 1:1:1 (BTCB1); 3:2:1 (BTCB2); 2:1:3 (BTCB3); 1:3:2 (BTCB4). Two control samples were made from a single bambaranut milk and tigernut milk. Each blend and single mix was sweetened with sugar syrup of $4 \%$ suspension solution in water and final emulsified with lecithin. The resultant mixture was homogenized at maximum speed in a Q-Link Blender (Model $356 \mathrm{XG}$ ) for 10 minutes. The product was pasteurized at $65^{\circ} \mathrm{C}$ for 30 minutes and bottled, then cooled under ambient condition as showed in Figure 4.

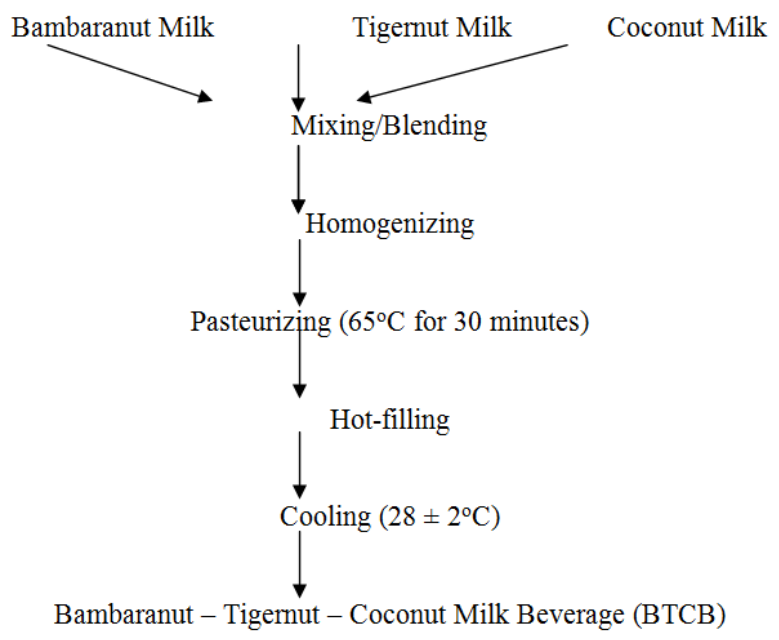

Figure 4. Flow chart for the production of Bambaranut - Tigernut Coconut Milk Beverage (BTCB)

\subsection{Mineral Profile Determination}

The method described by Onyeka ${ }^{(25)}$ was followed in the determination of mineral content of the pulp samples of African pear. Half gram $(0.5 \mathrm{~g})$ of the dry milled sample was weighed into a pre - acid rinsed digest tube. $10 \mathrm{~cm}^{3}$ of $6 \mathrm{M} \mathrm{HCl}$ was added and heated to dryness in a water bath. The residue was dissolved in a mixture of $10 \mathrm{~cm}^{3}$ of $6 \mathrm{M}$ $\mathrm{HNO}_{3}$ acid, warmed on a water bath and filtered using a Whatman filter paper into $100 \mathrm{~cm}^{3}$ calibrated flasks. The filter paper was washed with distilled water and the filtrate diluted with the distilled water and made up to the $100 \mathrm{~cm}^{3}$ mark. The digest was for the determination of calcium and potassium by the flame photometry method. The metals such as $\mathrm{Fe}, \mathrm{Zn}, \mathrm{P}$ and $\mathrm{Mg}$ were determined using the atomic 
absorption spectrophotometer method.

\subsection{Statistical Analysis}

The data obtained from different analyses were subjected to various statistical analyses which include simple descriptive mean, standard deviation and Analyses of Variance (ANOVA) using SPSS 17.0 Software.

\section{Resultsand Discussion}

Table 1 shows the mineral content of milk beverage blends produced from varied proportion of bambaranut tigernut - coconut milk extract. The mineral content of the milk beverage varied in value among the blends. However, the values of mineral contents of the blends obtained was lower when compared with standards recommended for dairy whole milk by the International Dairy Federation ${ }^{(4)}$. Values of mineral element per $100 \mathrm{~g}$ ranged from 8.34
$18.20 \mathrm{mg}$ calcium, $1.82-4.24 \mathrm{mg}$ potassium, $0.86-2.25 \mathrm{mg}$ iron, $1.02-3.38 \mathrm{mg}$ zinc, $1.15-2.97 \mathrm{mg}$ phosphorous and $0.87-1.24 \mathrm{mg}$ magnesium. The findings from this work differed from Belewu and Abodunrin ${ }^{(26)}$ who reported mineral content of tigernut milk beverage $\mathrm{mg} / 100 \mathrm{~g}$ of $\mathrm{Ca}$, $\mathrm{Mg}, \mathrm{K}$, and $\mathrm{P}$ as $0.40,0.20,1.90$ and 0.30 respectively. Again, Mason (2005) reported per $100 \mathrm{~g}$ as $245 \mathrm{mg}$, 92mg, $93 \mathrm{mg}$, and $424 \mathrm{mg}$ for $\mathrm{Ca}, \mathrm{Mg}, \mathrm{K}$, and $\mathrm{P}$ respectively. The variation among the findings from the different works in non-dairy milk beverage may be as a result of differences in the mineral composition of soil, the type of soil and location where the crop is planted ${ }^{(27)}$.In addition, variation could be attributed to differences arising from the methods of production adopted by different researcher. Onyeka ${ }^{(25)}$ reported that mineral elements are inorganic that are found in traces and play important roles in human nutrition and their inadequacy may result to nutritional disorder in human body.

Table 1. Mineral Content ofBambaranut - Tigernut - Coconut Milk Blends

\begin{tabular}{|c|c|c|c|c|c|c|}
\hline Blend of Milk Beverage & CalciumMg/100g & PotassiumMg/100g & IronMg/100g & ZincMg/100g & $\begin{array}{l}\text { Phosphorou } \\
\text { Mg/100g }\end{array}$ & $\begin{array}{l}\text { Magnesium } \\
\mathrm{Mg} / \mathbf{1 0 0 g}\end{array}$ \\
\hline BTC-B 1 & 10.22 & 1.82 & 0.86 & 1.02 & 1.15 & 0.87 \\
\hline BTC-B 2 & 13.63 & 3.08 & 2.18 & 3.11 & 2.97 & 1.24 \\
\hline BTC-B 3 & 11.72 & 2.88 & 1.84 & 2.63 & 1.62 & 1.16 \\
\hline BTC-B 4 & 11.08 & 2.32 & 1.58 & 1.98 & 2.01 & 0.98 \\
\hline TM-Control & 8.34 & 2.48 & 2.04 & 2.08 & 1.98 & 1.02 \\
\hline BM-Control & 18.20 & 4.24 & 2.25 & 3.38 & 1.68 & 1.24 \\
\hline $\begin{array}{l}\text { IDF Reference for } \\
\text { Whole Milk }\end{array}$ & 120 & 87 & 80 & 7 & 10 & $0.8-1.5$ \\
\hline
\end{tabular}

IDF $=$ International Dairy Federation ${ }^{(4)}$

Key:

BTC-B $\mathrm{B}_{1}=$ Milk beverage blend of 1:1:1 ratio of bambaranut: tigernut: coconut extract

$\mathrm{BTC}-\mathrm{B}_{2}=$ Milk beverage blend of 3:2:1 ratio of bambaranut: tigernut: coconut extract

BTC- $\mathrm{B}_{3}=$ Milk beverage blend of 2:1:3 ratio of bambaranut: tigernut: coconut extract

BTC- $B_{4}=$ Milk beverage blend of 1:3:2 ratio of bambaranut: tigernut: coconut extract

TM-Control=Milk beverage contained $100 \%$ tigernut extract

BM-Control $=$ Milk beverage contained $100 \%$ bambaranut extract

\section{Conclusion}

This study showed that non-dairy milk beverage produced from mixed blends of aqueous extracts from bambaranut - tigernut - coconut with improved nutritional quality was obtained from this work. The mineral content of milk beverage blends when compared with the standards found in dairy whole milk will give good nutritional quality, most especially in rural communities in developing countries where accessibility and cost of dairy products as a whole are major challenges of the people. These findings further supports most of the earlier studies on milk analogue from vegetable source as means of alleviating malnutrition in most developing countries such as Nigeria.

We therefore recommend that nutritional public enlightenment on the method of preparation and the plant milk from vegetable source (such as bambaranut, tigernut, coconut, etc) should be conducted both at the local communities and the cities of the developing countries.

\section{References}

[1] Wong, Venessa (2013). "Soy Milk Fades as Americans Opt for Drinkable Almonds". BusinessWeek.

[2] Epperly, V. D. (2008) Lifestyle Fasting Cook Book. Xulon Press, 2008, pp. 248-250.

[3] Belewu M.A and Belewu K.Y (2007): Comparative Physico-Chemical Evaluation of Tigernut, Soyabean and Coconut Milk Sources. Int. J. Agri. Boil., 9(5): 785 - 787.

[4] International Dairy Federation (IDF) (2008). Minerals in milk and milk products.www.idfdairynutrition.org.

[5] Sun-young P, K.S Marsh, Y.S Jenny and S.E Yun (2000): A Study on a Processing Method to Improve SoyMilk Quality. Proceedings of Pre-congress Internet Conference, May 8, Dec. 31 , pp:31 - 32 . 
[6] Obizoba I.C and Egbunna H.I (1992): Effect of germination of Fermentation on the Nutritional Quality of Bambaranut (agndzie subterranean Thourars) and its Products (Milk). Plant Foods Hum. Nutr., 42:13 - 23.

[7] Akubor, P.I (1998): Physico-chemical and Sensory Characteristics of Melon Seed Milk. J. Food Sci,; 35: $93-$ 95.

[8] Obizoba I.C and J.U Anyika (1995): Nutritive Value of Baobab Milk (AdansoniadigitataL), Hungary Rice, Acha (Digitannaexillis) Flours. Plant Foods for Hum. Nutr., $46: 156-165$

[9] Odo F.O (2001): Consumer Acceptance of Groundnut Milk. Proceedings of the $25^{\text {th }}$ Annual Conference of the Nigerian Institute of Food Sci. and Tech. (NIFST). November 5 - 9, Lagos, Nigeria, pp. 135 - 137.

[10] Ukwuru M.U, Omachona L.J and Onokah N (2008): Production and Quality Assessment of Tigernut (Cyperusesculentus) Imitation Milk during Storage. J. Food Sci. Technol., 45:180 - 182.

[11] Osagie A.U and S.A Eka (1998): Lipid from Plant Source, Structure and Distribution. Proc. 1st Agric. Conf. on Biochemistry of Lipids; 103:21 - 26 .

[12] Temple V.J (1998): Lesser Known Plant Foods. In: Nutritional Quality of Plant Foods. J. Food Tech., 35:93 95.

[13] Temple V.J, T.O Ojobe and N.M Kapu (1990): Chemical Analysis of Tigernut (Cyperusesculentus). J. Sci. Food Agric., 50:262 - 263.

[14] Ojobe T.O and Tempo V.J (1983): Amino Acid Composition of Tigernut Tubers (Cyperusesculentus). Nig. J. Sci. Biotechnol., 2:35 - 38 .

[15] FAO/WHO (2002): Milk and Milk Products. Joint FAO/WHO Food Standards Programme. CODEX AlimentariusCommossion, Pp:42.

[16] FAO/WHO (2002): Joint FAO/WHO Expert Report on Diet, Nutrition and the Prevention of Chronic Diseases, cited in Food and Nutrition Bulletin, 24: 255 - 256.

[17] Bosch L, Alegria A and Farri R (2005): RP-HPLC Determination of Tigernut and Orgeat Amino Acid Contents. Food Sci. Technol. Inter., 11:33 - 40.
[18] Goli A.E (1995): Bambara Groundnut, Bibliographical Review. In: Bambara Groundnut (Vigna subterranean (L.) Verdc.). Promoting the Conservation and use of Underutilized and Neglected Crops. (Editors: Heller J, Begemann $\mathrm{F}$ and Mushonga J). proceedings of the workshop on Conservation and Improvement of Bambara Groundnut (Vigna subterranean (L.) Verdc.), $14-16^{\text {th }}$ November, 1995, Harare, Zimbabwe, pp. $84-86$.

[19] Adedokun I.I, Okorie S.U, Onyeneke E.N and Anoruo S.A, (2013): Evaluation of Yield, Sensory and Chemical Characteristics of Soft Unripened Cheese produced with partial incorporation of Bambaranut Milk. Academia Journal of Food Research 1(1): $014-018$.

[20] Omoikhoje S.O and Arijeniwa A (2004): Effect of Heat Treatments on Proximate and Mineral Compositions of Bambara Groundnut (Vignasubterranea). In: Sustaining Livestock Production under Changing Economic Fortunes. (Editors: Tukur H.M, Hassan W.A, Maigandi S.A, Ipinjolu J.K, Daneji A.I, Baba).

[21] Rehman S, Mushtaq A.M, Yameen A, Almas K and muntaha S (2004): Sensory and Nutritional Evaluation of CoconutNatural Milk Blend. Pak. J. Life Soc. Sci. 2(2): $104-108$.

[22] Parsley J.G (1992): Replanting of the Tree of Life, CAB International Wallingford Oxon, pp. $38-40$.

[23] Nieuwentus R, Nieuwelink J (2002): Agrodok Series No. 10 CTA: The Netherlands, Pp. $28-30$.

[24] Udeozor L.O (2012): Tigernut-Soy Milk Drink: Preparation, Proximate Composition and Sensory Qualities. International Journal of Food and Nutrition Science, Vol. 1(4), pp 18 - 26.

[25] Onyeka E.U (2008): Mineral Elements and their Importance in: Food and Nutrition. 2nd Edition. Charismatic Publisher, Owerri.

[26] Belewu M.A and Abodurin O.A (2005): Preparation of Kunnu from Unexploited Plant in Nigeria.

[27] Adgidzi, E.A, Ingbian E.K, Abu J.O, (2011): Effects of Hot Water and Steam Blanching on the Quality of Acqueous Extract from Tigernuts (Cyperusesculentus) PAT June 2011; 7(1): $90-102$. 